\title{
EFFECT OF PARTIALLY OR TOTALLY REPLACING SOYBEAN MEAL BY GUAR KORMA MEAL ON SHEEP AND COWS PERFORMANCE MILK PRODUCTION.
}

Soliman M.S. ${ }^{*}$; A. M.El- Okazy ${ }^{\star}$ and Salma H. Abu Hafsa**

${ }^{*}$ Regional Centre for Food Feed, Agriculture Research Centre, Ministry of Agriculture, Dokki, Egypt;

**Livestock Research Department, Arid Lands Cultivation Research Institute, City of Scientific Research and Technology Applications, New Burg-Elarab, Alexandria, Egypt.

\begin{abstract}
This study was carried out to determine the effects of using different levels of Guar korma meal $\left({ }^{*} \mathrm{GK}\right)$ on milk yield and milk composition, rumen function of experimental rations fed to sheep and dairy cows. Animals were fed one of from experimental rations, control ration with $0 \%$ GK or rations with $5 \%, 10 \%$ and $15 \%$ GK. Animals fed rations containing guar korma showed linear decrease $(P<0.05)$ of total dry matter intake (DMI) with increasing ration guar korma meal level inclusion in rations. Twelve Barki male sheep were assigned randomly into 4 similar groups of 3 animals each to determine the digestibility coefficients, nitrogen balance and nutritive values of experimental rations. Results of digestibility trails showed that there were no significant differences $(\mathrm{P}<0.05)$ in digestibility of $\mathrm{DM}, \mathrm{OM}$ and $\mathrm{CP}$ for ration containing $10 \%$ GK compared to the control ration. While, there was significant $(P<0.05)$ decrease rations containing 5\%, 15\% guar korma. Similar trend recorded for the nutritive values. However, nitrogen utilization showed positive nitrogen balance with all animals fed the experimental rations. Three cannulated female Barki sheep were used to determined rumen fermentation parameters. The main results showed no significant differences among experimental groups in the values of ruminal $\mathrm{pH}$ and $\mathrm{NH}_{3}-\mathrm{N}$ concentrations, while the highest $(P<0.05)$ of TVFA'S concentrates were observed with the ration containing $10 \% \mathrm{GK}$ and the control ration than rations containing 5\%,15\% guar korma. Dry matter and CP degradability showed significant $(P<0.05)$ increased for rations containing GK than the control ration. Eight lactating crossbred Friesian cows were used to determine milk yield and milk composition. Cows fed ration containing $5 \%$ GK showed slight improvement in milk yield in comparison with the control ration. However Milk fat $(\%)$ increased $(P<0.05)$ for rations containing guar meals compared with the control ration.

${ }^{*} \mathrm{GK}=$ guar korma meal
\end{abstract}

\section{INTRODUCTION}

Guar seed (Cyamopsis tetragonoloba) is a multi-purpose annual herbaceous legume which is drought tolerant and cultivated mainly in the autumn season in arid environments as in Brazil, Australia and South Africa or in the Southern part of the USA, as Texas or Arizona. The current average productivity of guar seed is $0.7-2.5 \mathrm{t} / \mathrm{ha}$ of seeds. Average (1.6ton/ ha) has been reported by Wong et al., (1997), Ecocrop, (2010). Purushottam Sharma (2009) reported that the Current production of guar seed is 4.3 million tons from 2.82 million hectares under cultivation. India produces about $80 \%$ of world production, and about 2 million tones of guar meal are produced and 
utilized in the manufacture of guar gum from the endosperm. The germ and the husks are removed by grinding and dry heating to obtain the guar gum. Lee et al. (2004), found that the guar seed comprise of (three parts: the seed coat $(14-17 \%)$, the endosperm (35-42\%), and the germ (43-47\%). The resulting by-product made of germs and husks (guar korma meal). Guar korma Meal is rich in protein and carbohydrates, and is a $100 \%$ natural agricultural product without the addition of any chemicals or preservatives. Processed guar meal can be used in conjunction with other feed stuffs, in feed rations. Feeding characteristics and other properties of guar meal have been well evaluated in poultry nutrition by several authors including Couch et al., (1967), Verma and McNab (1982), lee et al (2009) and Hassan et al., (2010). However, few experiments have been done to evaluate the nutritive value of different guar meals for ruminant nutrition. The aim of study, the present study is to examine the utilization of guar korma meal as a protein source in ruminants rations, and investigate the effect of replacing guar korma meal with soybean meal on feed intake, nutritive value, rumen function, protein degradability in sheep and Milk yield and its composition in dairy cows.

\section{MATERIALS AND METHODS}

This work was conducted at Noubaria Experimental Station, Animal Production Research Institute, Agricultural Research Center, Ministry of Agriculture

\section{Experimental Rations:}

Four experimental rations were formulated to contain $5 \%, 10 \%$ and $15 \%$ guar korma of total concentrate mixed ration, and replacing dietary soybean meal (SBM).

As follows:-

1. R1 (Control) \%0 guar korma meal

2. R2 \%5 guar korma meal

3. R3 \%10 guar korma meal

4. R4 \%15 guar korma meal

$15 \%$ soybean meal $10 \%$ soybean meal $5 \%$ soybean meal $0 \%$ soybean meal

The chemical analysis of Guar Korma,concentrate feed mixed (CFM) and rice straw is presented in table (1). The chemical analysis of experimental rations is presented in table (2). 
Table (1): Chemical analysis of guar korma meal, the concentrate feed mixture and rice straw used in the experimental rations.

\begin{tabular}{|c|c|c|c|c|c|c|}
\hline Item & $\begin{array}{c}\text { Gura } \\
\text { korma } \\
\text { meal }\end{array}$ & Rice Straw & CFM1 & CFM2 & CFM3 & CFM4 \\
\hline Yellow corn & & & 36.0 & 36.0 & 36.0 & 36.0 \\
\hline Wheat bran & & & 26.0 & 26.0 & 26.0 & 26.0 \\
\hline Soybean meal & & & 15.0 & 10.0 & 5.0 & 0.00 \\
\hline Gura korma meal & & & 0.0 & 5.0 & 10.0 & 15.0 \\
\hline Sugar beet pulp & & & 9.0 & 9.0 & 9.0 & 9.0 \\
\hline Olive cake & & & 6.0 & 6.0 & 6.0 & 6.0 \\
\hline Molasses & & & 5.0 & 5.0 & 5.0 & 5.0 \\
\hline Salt & & & 1.0 & 1.0 & 1.0 & 1.0 \\
\hline Limestone & & & 1.5 & 1.5 & 1.5 & 1.5 \\
\hline Premix $^{*}$ & & & 0.5 & 0.5 & 0.5 & 0.5 \\
\hline Total & & & 100 & 100 & 100 & 100 \\
\hline \multicolumn{7}{|c|}{ Chemical analysis (\% on DM): } \\
\hline DM & 92.00 & 89.50 & 89.14 & 89.42 & 88.95 & 88.86 \\
\hline $\mathrm{OM}$ & 94.60 & 86.48 & 93.24 & 93.05 & 92.16 & 93.07 \\
\hline $\mathrm{CP}$ & 55.80 & 3.20 & 15.24 & 15.55 & 15.96 & 16.31 \\
\hline CF & 7.50 & 36.75 & 6.86 & 7.25 & 7.54 & 7.84 \\
\hline EE & 4.70 & 0.95 & 2.65 & 2.78 & 2.98 & 3.20 \\
\hline NFE & 26.60 & 44.58 & 68.49 & 67.47 & 66.68 & 65.72 \\
\hline Ash & 5.40 & 14.52 & 6.76 & 6.95 & 6.84 & 6.95 \\
\hline NDF & 25.50 & 69.42 & 30.65 & 30.91 & 31.32 & 31.47 \\
\hline ADF & 12.90 & 52.10 & 16.87 & 17.44 & 17.97 & 18.39 \\
\hline ADL & 5.34 & 12.54 & 4.76 & 5.04 & 5.22 & 5.39 \\
\hline Hemi cellulose & 12.60 & 17.32 & 13.78 & 13.47 & 13.35 & 13.08 \\
\hline Cellulose & 7.56 & 39.56 & 12.11 & 12.40 & 12.75 & 13.00 \\
\hline
\end{tabular}

* One kilogram of premix contain: Vit. A 12000000 IU, Vit. D3 220000 IU, Vit. E 1000 mg, Vit. B1 $1000 \mathrm{mg}$, Vit. B2 $4000 \mathrm{mg}$, Vit b6 $100 \mathrm{mg}$, Vit b12 $10 \mathrm{mg}$, Pantothenic acid $3.33 \mathrm{~g}$, Biotin $33 \mathrm{mg}$, folic acid $0.83 \mathrm{~g}$, Zn 11.79g, Mn $5 \mathrm{~g}$, Fe $12.5 \mathrm{~g}, \mathrm{Cu} \mathrm{0,5} \mathrm{g}$, Se $16.6 \mathrm{mg}$ and $\mathrm{Mg}$ $66.7 \mathrm{~g}$.

CFM1=15\%SBM, 0\%GK. CFM2=10\%SBM, 5\%GK. CFM3= 5\%SBM, 10GK. CFM4= 0\%SBM, $15 \%$ GK.

\section{Digestibility trails:}

Twelve Barki male sheep were assigned randomly into 4 similar groups of 3 each (48kg, live body weight) were used in digestibility trials. Each digestibility trial lasted two weeks as preliminary period followed by one week as a collection period. The animals were housed in metabolic cages fitted, a stainless steel screen having $4 \mathrm{~mm}$ mesh to retain feces but allow free passage to urine, which was collected through a funnel to be easily separated. The animals were fed twice a day at $8.00 \mathrm{am}$ and $16.00 \mathrm{pm}$ according to the NRC (1994) recommendations. They were fed 850-g/ head/ day from the concentrate feed mixture plus $300 \mathrm{~g}$ rice straw to cover the maintenance requirement. Water was available in front of the animals all time. Feed samples were collected and prepared for proximate analysis.

Feces and urine were collected quantitatively once a day before the morning meal at 8.00 , and stored at $-10{ }^{\circ} \mathrm{C}$. The seven days combined collection was sampled then it was kept for routine analyses. Fecal samples were dried at $60{ }^{\circ} \mathrm{C}$ for 72 hours (partial drying) and ground through a one 
$\mathrm{mm}$ screen using a Wiley mill grinder. They were composite sample of $20 \mathrm{gm}$ each per treatment per animal for analyses. Digestibilities were determined and expressed on dry matter basis. Chemical analyses were carried out according to AOAC (1995), crude protein (CP) by Kjeldahl, while nitrogen free extract (NFE) was calculated by difference. Fiber fraction NDF (neutral detergent fiber), ADF (acid detergent fiber) and ADL (acid detergent lignin) were determined as described by Van Soest (1963).

Rumen fermentation parameters:

Three female sheep fitted with permanent rumen fistula (with an average of $45 \mathrm{~kg}$ live body weight), were used in rumen fermentation studies. Rumen samples were collected from each animal from the fistula of one; three and six hours after the morning feeding. Ruminal $\mathrm{pH}$ was determined directly by a Beckman $\mathrm{pH}$ meter. Fifty $\mathrm{ml}$ of rumen liquor were deproteinized using sulphoric acid $(50 \mathrm{ml} 0.1 \mathrm{~N})$ and volume was completed with water to $500 \mathrm{ml}$ in a volumetric flask and filtered the supernatant was used for determination of ammonia nitrogen using (MgO) distillation method AlRabbat, et al (1971). VFA'S were estimated using steam distillation as described by Warner (1964). Volatile fatty acid fractions were determined according to Erwin et al. (1961) using gas liquid Chromatography

In Situ Trials:

Polyester bags ( $100 \%$ Dacron polyester) with a mean pore size of 45 $\mu \mathrm{m}$ and $7 \times 15 \mathrm{~cm}$ had a surface area of about $210 \mathrm{~cm}^{2}$ were used at each incubation time. Approximately $3 \mathrm{~g}$ of ingredient CFM were placed in each bag. Bags were incubated in the rumen of each sheep and removed after 3 , $6,12,24,48$ and 72 hours. After the removal of the bags, they were washed under a gently flowing steam of tap water until the fluid was clear. Bags were drained, dried at $60^{\circ} \mathrm{C}$ for 72 hours, cooled in desiccators and weighed. Dry matter and nitrogen content were estimated according to the method of (A.O.A.C. 1995). Two bags were washed in running water for $15 \mathrm{~min}$. to determine the initial soluble fraction (a). The kinetics of DM and CP disappearances was studied by fitting the individual values to the following equation:

$\mathbf{P}=\mathbf{a}+\mathbf{b e}^{-\mathrm{C}(\mathrm{T}-\mathrm{Lt})}$

Proposed by Orskov and McDonald (1979) where P represents the disappearance after time $T$, Lt is lag time until the start of the degradation. The, $a, b$ and $c$ are estimates of soluble fraction, the degradable fraction and the rate of degradation, respectively. The effective rumen degradability (ED) was estimated according to Orskov and McDonald (1979). Rumen out flow rate (k) was assumed to be 0.05 per hour for concentrate (McDonald 1981).

$E D=a+b c / c+k$.

Lactation Trials:

Eight lactating crossbred Friesian cows used in duplicated $4 \times 4$ Latin squares design according to the mathematical models of Steel and Torrie (1980). Statistical analysis were carried out using the GLM adapted by SAS (2000). Cows were chosen according to body weight (500 kg in average). Each two cows were offered one of the experimental rations for 30 days. The first 10 days was considered as preliminary period followed by 20 days collection period. The daily rations fed to cows covered both the maintenance 
and production requirements. Maintenance requirement calculated according to (NRC, 1990) and requirement for the production was calculated from the preliminary period and also the previous milk yield according to Barney Harris (1992). Cows were fed at 8.00 a.m. and 16.00 p.m. and then were milked twice a day and milk samples were taken ( $1 \%$ of milk yield/ period) during the last 20 days of each period at 8.00 and 16.00 . Actual milk yields were recorded daily and milk samples were taken and kept at $4{ }^{\circ} \mathrm{C}$ for latter analysis. Fat correct milk (4\%) was calculated according to Gaines (1923) using the following equation: $\mathrm{FCM}=\mathrm{M}(0.4+0.15 \mathrm{~F} \%)$

Where $\mathrm{M}=$ milk yield

$$
\mathrm{F}=\text { fat percentage }
$$

Milk fat percentage was determined according to Gerber's method as described by Ling (1963). Total solids percent (TS), total protein and ash were determined according to the standard methods of A.O.A.C. (1995). Lactose was determined according to a rapid method for the determination of lactose in milk and cheese described by John et al. (1957). Solid not fat (SNF) was calculated by differences.

Table (2): chemical analysis content of Experimental Ratios:

\begin{tabular}{|l|c|c|c|c|}
\hline \multirow{2}{*}{ Item } & \multicolumn{4}{|c|}{ Experimental rations } \\
\cline { 2 - 5 } & $\mathbf{R 1}$ & $\mathbf{R 2}$ & $\mathbf{R 3}$ & $\mathbf{R 4}$ \\
\hline DM & 89.89 & 90.10 & 89.73 & 89.72 \\
\hline OM & 91.40 & 91.15 & 91.24 & 91.14 \\
\hline CP & 12.10 & 12.28 & 12.52 & 12.72 \\
\hline CF & 14.71 & 15.10 & 15.43 & 15.76 \\
\hline EE & 2.23 & 2.29 & 2.40 & 2.58 \\
\hline NFE & 62.36 & 61.48 & 60.79 & 59.97 \\
\hline Ash & 8.60 & 8.85 & 8.86 & 8.97 \\
\hline NDF & 40.79 & 41.1 & 41.58 & 41.83 \\
\hline ADF & 26.10 & 26.60 & $\mathbf{2 7 . 1 6}$ & 27.59 \\
\hline ADL & 6.79 & 7.02 & 7.20 & 7.34 \\
\hline Hemi cellulose & 14.69 & 14.50 & 14.42 & 14.24 \\
\hline Cellulose & 19.31 & 19.58 & 19.96 & 20.25 \\
\hline
\end{tabular}

\section{RESULTS AND DISCUSSION}

Feed intake, digestibility coefficients, nutritive values and nitrogen utilization data is presented in table (2). Feed intake showed that, total dry matter intake (DMI) of rations containing $10,15 \%$ guar korma meal was less than the ration containing $5 \%$ and the control rations these differences were statistically significant at $(\mathrm{P}<0.05)$. No significant differences were recorded between ration containing $5 \%$ guar korma and the control. Similar trend was recorded for the sheep fed CFM. These results were in-agreement with those obtained by Hossein et al (2010) who reported linear decrease $(P<0.001)$ of total (DMI) for animals given more than $10 \%$ of guar korma. This decrease was most likely due to the some of the beans odor and gum residual from guar korma meal Morteza and Qazvinian (2003) found that increasing DMI was associated with decreasing guar meal percentage in diets.On the other 
hand Rahman et al (1968), reported that palatability problems have been encountered when more than $5 \%$ guar meal was included in the diet.

Data presented in table (2) indicated that animals fed R1 and R3 showed highest $(\mathrm{P}<0.05)$ digestibility values of $\mathrm{DM}, \mathrm{OM}$, and $\mathrm{CP}$ compared with other rations. Prasad et al., (1998) Found that the rate of CP digestion decreases with increasing the proportion of guar meal in broiler rabbits diets. Also, Huston and Shelton (1971) showed that the CP digestibility of guar meal was $64 \%$ and $62 \%$ in rations contained $10,15 \%$ guar meal respectively. Islam Shah et al (1964) reported that OM digestibilities ranged from $71 \%$ and $76 \%$ when guar meal constitutes up to $10 \%$ of cattle rations. Digestibility of CF is mainly dependent upon the concentration and availability of holocellulose (cellulose and hemicellulose) portion which is affected by the degree of lignification Smith et al (1971). The present study showed that the ADF and cellulose increasing linearly with increasing level of guar korma meal in rations, this led to decreasing CF digestibility for rations containing guar korma than the control ration $(\mathrm{P}<0.05)$. These results were in agreement with those reported by Bhagwan et al (1974). On the other hand, the present results (table 2) indicated that the nutritive value as TDN and DCP increased significantly $(P<0.05)$ for animals fed Ration1 and Ration3. While, animals fed Rations 2, 4 recorded the lowest values $(P<0.05)$. Nitrogen utilization values are present in table (2). All animals showed positive nitrogen balance which ranged between 3.47 and $4.25 \mathrm{gm} \mathrm{N} /$ day. Highest values were obtained with sheep fed R1 and R3 however, the lowest were observed with $R 4$ with significant differences $(P<0.05)$.

Table (3): Digestibility coefficients, nutritive values and nitrogen utilization of sheep given the experimental rations.

\begin{tabular}{|c|c|c|c|c|}
\hline Item & \multicolumn{4}{|c|}{ Experimental rations } \\
\hline & R1 & R2 & R3 & R4 \\
\hline $\mathrm{CFM}^{*}(\mathrm{~g} / \mathrm{d} / \mathrm{head})$ & $850.00 \pm 72.76^{a}$ & $835.00 \pm 67.64^{a}$ & $813.5 \pm 71.85^{b}$ & $798.5 \pm 68.89^{c}$ \\
\hline $\mathrm{RS}^{\star *} \quad(\mathrm{~g} / \mathrm{d} / \mathrm{head})$ & 300.00 & 300.00 & 300.00 & 300.00 \\
\hline TDMI (g/d/head) & $1150.00 \pm 92.42^{\mathrm{a}}$ & $1135.00 \pm 87.15^{\mathrm{a}}$ & $1113.50 \pm 89.56^{b}$ & $1098.50 \pm 86.85^{c}$ \\
\hline \multicolumn{5}{|c|}{ Digestibility coefficients (\%): } \\
\hline DM & $62.79 \pm 0.62^{\mathrm{a}}$ & $60.14 \pm 0.61^{b}$ & $63.11 \pm 0.63^{\mathrm{a}}$ & $58.05 \pm 0.52^{c}$ \\
\hline OM & $66.51 \pm 0.55^{\mathrm{b}}$ & $65.04 \pm 0.53^{c}$ & $67.39 \pm 0.60^{\mathrm{a}}$ & $62.23 \pm 0.57^{d}$ \\
\hline $\mathrm{CP}$ & $60.59 \pm 0.71^{a}$ & $57.81 \pm 0.65^{\mathrm{b}}$ & $59.09 \pm 0.59^{a}$ & $57.28 \pm 1.75^{b}$ \\
\hline CF & $62.35 \pm 0.68^{a}$ & $61.96 \pm 0.84^{b}$ & $59.03 \pm 0.75^{b}$ & $57.84 \pm 0.81^{c}$ \\
\hline EE & $71.32 \pm 0.91^{\mathrm{a}}$ & $71.51 \pm 0.96^{\mathrm{a}}$ & $70.26 \pm 0.92^{c}$ & $71.03 \pm 0.87^{b}$ \\
\hline NFE & $68.71 \pm 0.71^{\mathrm{a}}$ & $67.60 \pm 0.75^{\mathrm{b}}$ & $69.09 \pm 0.72^{\mathrm{a}}$ & $65.72 \pm 0.69^{c}$ \\
\hline \multicolumn{5}{|c|}{ Nutritive value (\%) } \\
\hline TDN & $62.93 \pm 0.76^{a}$ & $61.70 \pm 0.71^{\mathrm{b}}$ & $62.30 \pm 0.78^{a}$ & $59.93 .08 \pm 0.67^{c}$ \\
\hline DCP & $7.33 \pm 0.14^{\mathrm{a}}$ & $7.10 \pm 0.12^{c}$ & $7.39 \pm 0.11^{\mathrm{a}}$ & $7.29 \pm 0.15^{\mathrm{b}}$ \\
\hline \multicolumn{5}{|c|}{ Nitrogen utilization: } \\
\hline $\mathrm{N}$-Intake (NI) & $22.26 \pm 0.25^{b}$ & $22.30 \pm 0.22^{\mathrm{a}}$ & $22.31 \pm 0.18^{a}$ & $22.36 \pm 0.16^{\mathrm{a}}$ \\
\hline N-Digested (ND) & $13.50 \pm 0.34^{a}$ & $12.77 \pm 0.27^{c}$ & $13.19 \pm 0.28^{b}$ & $13.03 \pm 0.29^{b}$ \\
\hline $\mathrm{N}$ - Urine (NU) & $9.44 \pm 0.51^{a}$ & $8.99 \pm 0.58^{b}$ & $9.04 \pm 0.52^{b}$ & $9.46 \pm 0.65^{a}$ \\
\hline N-Balance (NB) & $4.06 \pm 0.14^{\mathrm{a}}$ & $3.78 \pm 0.11^{\mathrm{b}}$ & $4.15 \pm 0.07^{a}$ & $3.57 \pm 0.19^{b}$ \\
\hline $\mathrm{NB} / \mathrm{NI}$ & $18.24 \pm 0.13^{a}$ & $17.00 \pm 0.16^{\mathrm{b}}$ & $18.60 \pm 0.11^{a}$ & $15.97 \pm 0.15^{c}$ \\
\hline NB/ND & $30.07 \pm 0.24^{b}$ & $29.61 \pm 0.28^{b}$ & $31.46 \pm 0.27^{a}$ & $27.39 \pm 0.26^{c}$ \\
\hline
\end{tabular}

$a,, b, c$ and $d$ Means in the same row with different superscript are significantly $(P<0.05)$.

${ }^{\star} \mathrm{CFM}=$ concentrate feed mixture, ${ }^{\star \star} \mathrm{RS}=$ rice straw 


\section{Rumen fermentation parameters and VFA production.}

The results of ruminal parameters which is presented in table (3) showed insignificant differences $(P<0.05)$ among experimental animals in the values of ruminal $\mathrm{pH}$ and $\mathrm{NH}_{3}-\mathrm{N}$ concentration. However the animals fed rations containing guar korma recorded slightly higher $\mathrm{NH}_{3}-\mathrm{N}$ concentration compared with the control animals results there were in agreement with those obtained by Santra and Karim(2009) who found that total nitrogen and ammonia nitrogen production increased with increasing guar korma in the rations. On the other hand the control ration and $\mathrm{R} 3$ recorded $(\mathrm{P}<0.05)$ higher total VFA concentration compared with R2 and R4.This improvement in TVFA'S may be due to the increasing of digestibility of organic matter kholif et al (2005), El-Ashry et al., (2003). Generally, the level of ammonia and TVFA'S concentrations were adequate enough to allow maximum microbial protein synthesis according to McCarthy et al., (1989). There was a linear increase $(P<0.05)$ in acetic acid percentage and acetic/ propionic acid ratio as the level of guar korma meal increased in the rations, these results were in agreement with those of Bhagwan et al., (1974) who reported that supplementation with guar meal in ruminates rations led to significant increase $(\mathrm{P}<0.05)$ in acetic: propionic acid ratio.

Table (4): Overall means with their SE of rumen parameters of sheep fed the experimental Rations (means $\pm \mathrm{SE}$ ).

\begin{tabular}{|l|c|c|c|c|}
\hline \multirow{2}{*}{ Items } & \multicolumn{4}{|c|}{ Experimental rations } \\
\cline { 2 - 5 } & $\mathbf{R}_{\mathbf{1}}$ & $\mathbf{R}_{\mathbf{2}}$ & $\mathbf{R}_{\mathbf{3}}$ & $\mathbf{R}_{\mathbf{4}}$ \\
\hline $\mathrm{Ph}$ & $6.54 \pm 0.11$ & $6.52 \pm 0.10$ & $6.50 \pm 0.05$ & $6.55 \pm 0.07$ \\
\hline $\begin{array}{l}\mathrm{NH}_{3}-\mathrm{N} \text { concentration } \\
\text { (mg/100mIR.L) }\end{array}$ & $13.47 \pm 0.12$ & $13.51 \pm 010$ & $13.55 \pm 0.15$ & $13.58 \pm 0.09$ \\
\hline $\begin{array}{l}\mathrm{VFA} \text { concentration } \\
\text { (meq/100 mIR.L) }\end{array}$ & $13.11 \pm 0.21^{\mathrm{a}}$ & $12.67 \pm 0.12^{\mathrm{b}}$ & $13.45 \pm 0.11^{\mathrm{a}}$ & $11.32 \pm 0.14^{\mathrm{c}}$ \\
\hline Acetic acid, \% & $51.66 \pm 0.31^{\mathrm{b}}$ & $53.43 \pm 0.25^{\mathrm{a}}$ & $54.37 \pm 0.16^{\mathrm{a}}$ & $54.70 \pm 0.22^{\mathrm{a}}$ \\
\hline propionic acid, \% & $24.33 \pm 0.19^{\mathrm{a}}$ & $24.12 \pm 0.11^{\mathrm{a}}$ & $23.07 \pm 0.08^{\mathrm{ab}}$ & $22.30 \pm 0.23^{\mathrm{b}}$ \\
\hline Butyric acid, \% & $12.80 \pm 0.13$ & $11.30 \pm 0.23$ & $11.70 \pm 0.17$ & $11.90 \pm 0.40$ \\
\hline Acetic /propionic ratio & $2.12 \pm 0.02^{\mathrm{b}}$ & $2.22 \pm 0.04^{\mathrm{b}}$ & $2.36 \pm 0.05^{\mathrm{a}}$ & $2.45 \pm 0.03^{\mathrm{a}}$ \\
\hline
\end{tabular}

\section{Degradation of dry matter and crude protein.}

Data in table (4) showed the in-situ DM and CP disappearance along with the effective degradability (ED) of DM and CP calculated for $\mathrm{k}=5 \% \mathrm{~h}^{-1}$ (ARC, 1984). Higher $(P<0.05)$ ED was recorded with ration containing $15 \%$ guar korma, followed by rations contained $10 \%$ and $5 \%$ guar korma. However, the control ration had a significantly lower $(P<0.05)$ ED of DM. These results disagreed with of Hossein et al (2010), who reported that applying heat treatment during processing of guar korma meal led to decrease the effective degradability of DM when compared with cotton meal. Supplementation with guar korma meal may have provided more readily available nutrients to the rumen microbes, potentially meeting their nutritional requirements of rumen microflora from rapidly degradable fraction (a) than 
control ration Mohsen et al., (2010). Also, similar trend was recorded for ED of CP degradability for rations containing guar korma meal which ranged from $63.21 \%$ to $66.04 \%$ those of being higher $(P<0.05)$ than control ration Lund et al., (2008) reported that $\mathrm{N}$ degradability for guar meal ranged between 60 $68 \%$. Our results were in-agreement with Mondal et al (2008) who found that Guar meal had higher rate of CP degradability than soybean meal and sunflower meal, also rapidly degradable fraction (a) was greatest in guar meal, with intermediate values in SBM.

Table(5):Degradation kinetics of DM and CP for sheep fed the experimental rations (mean $\pm \mathrm{SE}$ ).

\begin{tabular}{|c|c|c|c|c|}
\hline \multirow[t]{2}{*}{ Item } & \multicolumn{4}{|c|}{ Experimental rations } \\
\hline & R1 & R2 & R3 & $\mathbf{R 4}$ \\
\hline \multicolumn{5}{|c|}{ DM } \\
\hline$a, \%$ & $28.85 \pm 0.22^{b}$ & $30.37 \pm 0.54^{a}$ & $30.94 \pm 0.53^{a}$ & $31.23 \pm 0.34^{a}$ \\
\hline$b, \%$ & $57.21 \pm 0.23^{c}$ & $57.41 \pm 0.12^{b}$ & $59.34 \pm 0.16^{a}$ & $62.56 \pm 0.21^{a}$ \\
\hline c, $\%$ & $0.053 \pm 0.003^{c}$ & $0.054 \pm 0.001^{b}$ & $0.054 \pm 0.002^{a}$ & $0.056 \pm 0.001^{\mathrm{ab}}$ \\
\hline EDDM, \% & $58.29 \pm 0.29^{c}$ & $60.44 \pm 0.53^{b}$ & $61.75 \pm 0.33^{b}$ & $64.28 \pm 0.23^{a}$ \\
\hline \multicolumn{5}{|c|}{$\mathrm{CP}$} \\
\hline$a, \%$ & $22.56 \pm 0.32^{c}$ & $24.59 \pm 0.22^{b}$ & $24.05 \pm 0.24^{b}$ & $25.38 \pm 0.15^{a}$ \\
\hline$b, \%$ & $57.77 \pm 0.21^{\mathrm{c}}$ & $62.18 \pm 0.25^{b}$ & $62.88 \pm 0.27^{b}$ & $64.29 \pm 0.11^{\mathrm{a}}$ \\
\hline $\mathrm{C}, \%$ & $0.075 \pm 0.001^{\mathrm{c}}$ & $0.082 \pm 0.001^{b}$ & $0.080 \pm 0.002^{b}$ & $0.086 \pm 0.001^{a}$ \\
\hline EDCP, \% & $57.20 \pm 0.37^{c}$ & $63.21 \pm 0.21^{b}$ & $63.28 \pm 0.13^{b}$ & $66.04 \pm 0.11^{\mathrm{a}}$ \\
\hline
\end{tabular}

abc Means within column with different superscript are significantly differ $(P<0.05)$.

$a=$ soluble fraction $(\%) . \quad b=$ potentially degradable fraction $(\%)$.

$c=$ rate of degradability $\left(\% \mathrm{~h}^{-1}\right)$. $\quad E D=$ effective degradability $(\%)$.

\section{Milk yield and composition}

The daily milk, FCM (4\%) and Milk composition are presented in table (5). In general, cows fed on ration containing 5\% guar korma meal and control ration had highest $(\mathrm{P}<0.05)$ daily milk yield and FCM $(4 \%)$ compared with other rations. The results of this study were in-agreement with previous studies of Morteza and Qazvinian (2010), Rahman, and Leighton, (1968) who found that in dairy cows, palatability problems have been reported when more than $5 \%$ guar meal was included in the diet and also had negative effect on milk yield. However, dairy cows and heifers fed rations containing $10-15 \%$ guar meal got acquainted to its odor and taste after a few days and intake remained lower than the control ration as well as in dairy performances Rahman et al., (1968). On the other hand milk fat (\%)increased for rations containing guar korma meals compared with control ration $(P<0.05)$. These results are in-agreement with those of Safimahmed and Gulamraul (2013), who found that the milk fat \% of buffaloes fed ration containing guar meal was higher $(P<0.01)$ than those fed of control. This was associated with the increase in the proportion of acetic acid production Storry and Rook (1965). Milk protein was influenced by guar koma meal supplement $(P<0.05)$. Milk protein concentration was lowest $(P<0.05)$. for control ration than rations contain guar korma meal. 
Table (6): Milk yields and milk composition for lactating cross berd Friesian cows fed the experimental rations (mean $\pm \mathrm{SE})$.

\begin{tabular}{|l|c|c|c|c|}
\hline \multirow{2}{*}{ Item } & \multicolumn{4}{|c|}{ Experimental rations } \\
\cline { 2 - 5 } & $\mathbf{R 1}$ & $\mathbf{R 2}$ & $\mathbf{R 3}$ & R4 \\
\hline Milk yields, kg/d & $12.82 \pm 0.29^{\mathrm{a}}$ & $12.51 \pm 0.15^{\mathrm{a}}$ & $12.09 \pm 0.25^{\mathrm{b}}$ & $11.57 \pm 0.11^{\mathrm{c}}$ \\
\hline 4 \% FCM & $11.92 \pm 0.40^{\mathrm{a}}$ & $12.06 \pm 0.24^{\mathrm{a}}$ & $11.36 \pm 0.78^{\mathrm{b}}$ & $11.05 \pm 0.12^{\mathrm{c}}$ \\
\hline Fat, kg/d & $0.45 \pm 0.01^{\mathrm{ab}}$ & $0.47 \pm 0.01^{\mathrm{a}}$ & $0.44 \pm 0.03^{\mathrm{ab}}$ & $0.43 \pm 0.02^{\mathrm{b}}$ \\
\hline \multicolumn{4}{|c|}{ Milk composition (\%): } \\
\hline Total solids & $12.23 \pm 0.15^{\mathrm{b}}$ & $12.55 \pm 0.11^{\mathrm{a}}$ & $12.49 \pm 0.14^{\mathrm{a}}$ & $12.06 \pm 0.18^{\mathrm{b}}$ \\
\hline Solids not fat & $8.70 \pm 0.12^{\mathrm{ab}}$ & $8.79 \pm 0.25^{\mathrm{ab}}$ & $8.89 \pm 0.12^{\mathrm{a}}$ & $8.36 \pm 0.24^{\mathrm{b}}$ \\
\hline Fat & $3.53 \pm 0.15^{\mathrm{b}}$ & $3.76 \pm 0.22^{\mathrm{a}}$ & $3.60 \pm 0.12^{\mathrm{b}}$ & $3.70 \pm 0.18^{\mathrm{a}}$ \\
\hline Protein & $3.35 \pm 0.16^{\mathrm{b}}$ & $3.39 \pm 0.13^{\mathrm{a}}$ & $3.42 \pm 0.12^{\mathrm{a}}$ & $3.41 \pm 0.19^{\mathrm{a}}$ \\
\hline Lactose & $4.38 \pm 0.26^{\mathrm{a}}$ & $4.42 \pm 0.29^{\mathrm{a}}$ & $4.52 \pm 0.26^{\mathrm{a}}$ & $3.99 \pm 0.39^{\mathrm{b}}$ \\
\hline Ash & $0.97 \pm 0.05$ & $0.98 \pm 0.04$ & $0.95 \pm 0.03$ & $0.96 \pm 0.06$ \\
\hline
\end{tabular}

abc Means within rows with different superscript are significantly differ $(\mathrm{P}<0.05)$.

Economic efficiency:

The economic evaluations of feeding the experimental rations are presented in Table(6).

Milk price and feeding cost were calculated based on the market prices in the year 2013. It was clear that R4 was the cheapest ration to produce one $\mathrm{kg}$ milk yield, followed by the ration containing $10 \%$ guar korma. While, the control ration was the most expensive one.

The economic return (L.E. / h/ d) was higher for the ration which contained $5 \%$ guar korma and achieved an increased $3 \%$ in the economic returns than the control ration. The lowest return was recorded for ration containing $15 \%$ guar korma. These results proved that ration contained $5 \%$ guar korma improved the economic return (L.E. / h/ d).

Table (7): Economic efficiency for lactating cows fed the experimental rations (mean $\pm \mathrm{SE}$ ).

\begin{tabular}{|l|c|c|c|c|}
\hline Item & $\mathbf{R 1}$ & $\mathbf{R 2}$ & $\mathbf{R 3}$ & $\mathbf{R 4}$ \\
\hline CFM intake/h/day & $8.580 \pm 0.41^{\mathrm{a}}$ & $8.510 \pm 0.44^{\mathrm{a}}$ & $8.0150 \pm 0.42^{\mathrm{b}}$ & $7.850 \pm 038^{\mathrm{c}}$ \\
\hline Rice straw intake/h/day & $3.980 \pm 0.35^{\mathrm{b}}$ & $4.020 \pm 0.38^{\mathrm{ab}}$ & $4.120 \pm 0.34^{\mathrm{a}}$ & $4.215 \pm 0.33^{\mathrm{a}}$ \\
\hline Total intake/h/day & $12.55 \pm 0.73^{\mathrm{a}}$ & $12.538 \pm 0.81^{\mathrm{a}}$ & $12.135 \pm 0.79^{\mathrm{b}}$ & $11.965 \pm 0.76^{\mathrm{c}}$ \\
\hline $\begin{array}{l}\text { cost of total } \\
\text { feed/LE/h/day }\end{array}$ & 20.62 & 20.18 & 18.86 & 18.26 \\
\hline Price of milk yield(LE) & 59.60 & 60.30 & 56.80 & 55.25 \\
\hline Net revenue & 38.98 & 40.12 & 37.94 & 36.99 \\
\hline Economic Efficiency\% & 189 & 199 & 201 & 203 \\
\hline
\end{tabular}

abc Means within rows with different superscript are significantly differ $(\mathrm{P}<0.05)$.

Free market prices (LE/ton) for the feed ingredients used in formulating the experimental rations in the year (2013).

Soybean meal $=3925$, guar korma meal $=3225$, Yellow corn $=2650$, Wheat bran $=1750$, sugar beet pulp $=900$, olive cake $=800$

Molasses $=1050$, Salt $=150$, Limestone $=50$, Premix $=2000$. Rice straw $=390$, Price $/ \mathrm{kg}$ milk yield $4 \%$ fat $(L E)=5.00$

The price of one ton of CFM containing guar korma meal with rate of $0,5,10$ and $15 \%$ was 2222, 2187, 2152 and 2117 L.E respectively 


\section{CONCLUSION}

In conclusion, the present results demonstrated that substitution $10 \%$ of soybean meal with guar korma meal showed the best effect on nutritive values and $5 \%$ guar korma meal had the best effect on animal performance. However, as little information about nutritive values, kinetic of guar meal nutrient disappearances in ruminants are available therefore further work is needed to examine the possibility of using guar korma meal in possibly at higher levels in ruminant feeding.

\section{REFERENCES}

A.O.A.C. (1995). Multiresidue method (16 th Ed. 985.22) association official analytical chemists. Washington, Virginiall, U.S.A.

Agricultural Research Council.ARC, (1984). The Nutrient Requirements of Ruminant Livestock. Supplement No. 1., Commonwealth Agricultural Bureaux, Farnham Royal, UK, pp. $38 \pm 39$.

Al-Rabbat, M.F., R.L. Baldwin and W.C. Weir, (1971).In vitro nitrogen-treacer technique for some kinetic measures of rumen ammonia. J. Dairy Sci., $54,150$.

Barney Harris jr,(1992). Nutrient Requirements of Dairy Cattle. This document is Fact Sheet DS 38, of the Dairy Production Guide, originally published as part of Circular 594, Florida Cooperative Extension Service.

Bhagwan DAS, S. KA.R Ora, and Y. P. Luthra(1974). Variability in Structural Carbohy+drates and In Vitro Digestibility of Forages. 3. Guar (Cyamopsis tetragonoloba). J. Dairy Sci. 58:NO.9, 1347-1351.

Couch, J. R.; Y. K., Bakshi; Y. K, Freguson; T. M., Smith; E. B. and Greger, C. R. (1967). The Effect of Processing on the Nutritional Value of Guar Meal for Broiler Chicks. Br. Poult. Sci. 8: 243-250.

Ecocrop, (2010). Animal Feed Resources Information System.

El-Ashry, M.A., A.M.Kholif, M.Fadel, H.M. EL-Alamy, S.M.EL-Sayed and S.M. Kholif. (2003). Effect of biological treatments on chemical composition and in vivo digestibilities of poor quality roughages. Egyption J. Nutr. and Feed, 6: 113-126.

Erwin. E. S., G. J. Marrco and E. M. Emery (1961). Volatile fatty acids analysis of blood and rumen fluid by gas chromatography. J. Dairy Sci., $44: 1768$.

Gaines, W.L. (1923). Relation between percentage of fat content and yield of milk. 1. Correction of milk yield for fat content. Agric. Exo. Sta. Bull. 245 (C.F. Gaines, 1928).

Hassan, S. M., A. U. Haq, J. A. Byrd, M. A. Berhow, A. L. Cartwright and C. A., Bailey, (2010). Haemolytic and antimicrobial activities of saponinrich extracts from guar meal. Food Chem., 119: 600-605. 
Hossein, Jahani-Azizabadi, D.M. Mohsen, R. V.Ali, V.Moosa, E. Abdi Ghezeljeh and M.Mohsen, (2010). The Effect of Heat or Heat-Xylose Processing on Nitrogen Fractions and in Situ/In Vitro Ruminal and Post-Ruminal Protein Disappearance of Guar Meal. American Journal of Animal and Veterinary Sciences 5 (4): 266-273.

Huston, J. E. and M., Shelton, (1971). An evaluation of various protein concentrates for growing finishing lambs. J. Anim. Sci., 32: 334-338.

Islam Shah, S. S., M. B. Sial, and B. H., Schneider, (1964). The nutritive value of guar meal. J. Anim. Sci., $23: 892$.

John, A., G. Barnett and G. G. Abdel Tawab, (1957).A rapid method for determination of lactose in milk and cheese.J.Sci.Food Agric.,7:437441.

Kholif, A. M., H. A.El-Alamy, H.M. El-Sayed, M.A. El-Ashry and S. M. Kholif, (2005). Biological treatments of banana wastes for lactation cows feeding. Egyptian J. Nutrition and Feeds. 4 (special issue) 433-438.

Lee, J. T., C. A. Bailey and A. L. Cartwright, ( 2009). In vitro viscosity as a function of guar meal and beta-mannanase content of feeds. Int. J. Poult. Sci., 8 (8): 715-719.

Lee. J., A. Connor-Appleton, C. Haq, Bailey and A. Cartwright, ( 2004). Quantitative measurement of negligible trypsin inhibitor activity and nutrient analysis of guar meal fractions. J. Agric. Food Chem., 52. 6492-6495.

Ling, E.R. (1963). A Text Book of Dairy Chemistry. $3^{\text {rd }}$ Ed., Vol. П. Chapman and Hall Ltd., London.

Lund, P. M. R. Weisbjerg and T. Hvelplund, (2008). Profile of digested feed amino acids from untreated and expander treated feeds estimated using in situ methods in dairy cows. Livestock Sci., 114(1). 108-116.

McCarthy, R.D., T.H. Klusmeyer, J.L. Vicini, J.H. Clark and D.R., Nelson (1989). Effects of source of protein and carbohydrate on ruminal fermentation and passage of nutrients to the small intestine of lactating cows. J. Dairy Sci., 72, 2002-2016.

McDonald I. (1981). A revised model for the estimation of protein degradability in the rumen. J. Agric. Sci. 96: 251-252.

Mohsen D. M., J.-Azizabadi Hossein and V. Alireza. (2010). The effect of heat or heat-xylose processing on chemical composition and in vitro first order dry matter and crude protein disappearance kinetics of guar meal. World Academy of Science, Engineering and Technology 68 2179-2181.

Mondal, G.T., K. Walli and A.K. Patra (2008). In vitro and in sacco ruminal protein degradability of common Indian feed ingredients. Livestock Res. Rural Dev., 20 (4): 1-11.

Morteza, S.and K.Qazvinian, (2010). Effects of feeding different levels of guar meal on performance and blood metabolites in holstein lactating cows. Indian J. Anim. Nutr., 6(3): 274-278.

Morteza, S.and K.Qazvinian, (2003). Effects of feeding different levels of guar meal on performance and blood metabolites in holstein lactating cows. Lucrări Ştiinţifice - vol. 55, Seria Zootehnie, 196-200. 
N.R.C (1990). Nutrient requirements of dairy cattle. $7^{\text {th }}$ Ed., National Academy of Sciences. National Research Council, Washington, D.C.

National Research Council. (1994). Nutrient Requirements of sheep, 9th Revised Edition, National Academy Press, Washington, DC.

Orskov, E.R. and I. McDonald. (1979). The estimation of protein degradation in the rumen from incubation measurements weighted according to rate of passage. Journal of agriculture Science Cambridge 92: 499.

Prasad, R., S. K. Sankhyan, and S. A. Karim, 1998. Growth performance of broiler rabbits fed on diets containing various types of protein supplements. Indian J. Anim. Prod. Manage., 14 (4): 227-230

Purushottam Sharma (2009). Guar Industry Vision 2020: Single Vision Strategies.

Purushottam Sharma and K.C. Gummagolmath, (2012). Reforming Guar Industry in India: Issues and Strategies Agricultural Economics Research ReviewVol. 25(No.1) January-June 2012 pp 37-48.

Rahman, M. S., j.k.,Conrad and R. E. Leighton, (1968).Effect of replacing guar meal with soybean meal in dairy rations. J. Dairy Sci., 51 (10):1672-1681.

Santra, A. and S.A. Karim. (2009). Effect of dietary roughage and concentrate ratio on nutrient utilization and performance of ruminant animals. Animal Nutrition and Feed Technology, 9: 113-135.

Safimahmed, V. and P. S. Gulamraul, (2013). Effect of Feeding Bypass Nutrients on Milk Production and Composition in Buffaloes under Field Conditions. Indian Journal of Animal Nutrition.30 abstrac.

SAS (2000). SAS users guide: Statistics, SAS Inst., Inc., Cary N.C., USA.

Smith, L. W., H. K. Goering, D. R. Waldo and C. H. Gordon. ( 1971). In vitro digestion rate of forage cell wall components. J. Dairy Sci, 54:71.

Steel, R.G.D. and J.H. Torrie, (1980). Principles and procedures of statistics. Mc Graw-Hill, New York, $2^{\text {nd }} E$.

Storry, J. E and J. A. F. Rook, (1965). The effects in the cow of intraruminal infusions of acetic acid, propionic acid or butyric acid on the secretion of the component fatty acids of the milk fat and composition of the blood plasma. Biochem J. 96(1): 210-217.

Van Soest P J. (1963a). Use of detergents in the analysis of fibrous feeds. II. A rapid method for the determination of fiber and lignin. J. Ass. Offic. Agr. Chem. 46:829-35.

Verma, S. V. S. and J. M. McNab, (1982). Guar meal in diets for broiler chickens. Br. Poult. Sci., 23: 95-105.

Warner, A. C. I. (1964) "Production of Volatile Fatty Acids in the Rumen Methods of Measurement," Nutrition Abstracts \& Reviews, Vol. 34, pp. 339-352.

Wong, L. J., C. Parmar and van der Maesen,(1997). Record from Proseabase. Faridah Hanum, PROSEA (Plant Resources of SouthEast Asia) 


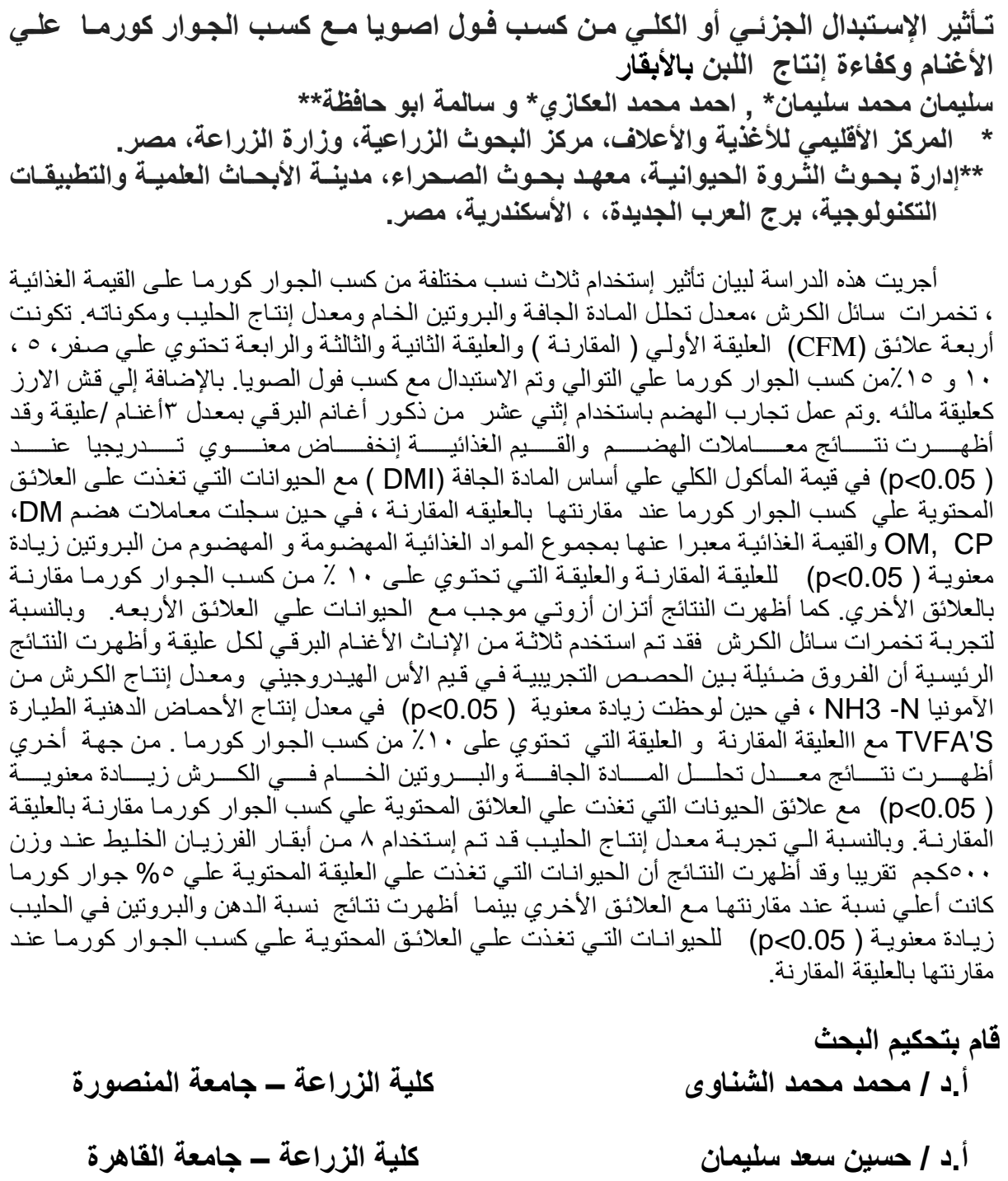

